\title{
Developments in the value-added efficiency of South African workers - an exploratory study
}

\author{
C. Morris* \\ School of Accountancy, University of Stellenbosch, Private Bag X1, Matieland, 7602 \\ *To whom all correspondence should be addressed \\ crutgers@sun.ac.za
}

\begin{abstract}
Human capital efficiency (HCE) refers to an employee's ability to create value-added for his employer. The purpose of this study is to investigate the movement in HCE of the workers of South African listed companies over time. The metric for HCE, value-added human capital (VAHU), is calculated as the value-added per Rand spent on employee costs. The median of the compound annual growth rate of VAHU was calculated for all JSE Main Board and ALT-X listed companies, per industry, over the financial years ended 31 December 2001 to 30 June 2011. This median growth was used to infer an improvement or deterioration in HCE. HCE was found to have declined in all South African industries, except Consumer Services, from 2001 to 2011. The overall decline is attributable to an over-emphasis on tangible physical resources; excessive compensation levels imposed by the 'strike' culture in South Africa; poor education and, possibly, to the overall economic decline after the global financial crisis of 2007. The government's drive for quality education has not translated into improved HCE. Companies may be forced to shoulder the cost of additional education and training themselves to further develop the basic skills of their employees.
\end{abstract}

\section{Introduction}

"A good employee pays for himself tenfold" (Garrett, 2013). That employee's ability to create value-added for his employer is referred to as human capital efficiency (HCE).

Human capital comprises the physical and intellectual capabilities acquired through education and training that enable an employee to perform tasks effectively and productively. As there is no consensus on the definition of human capital, the characteristics described by Tseng and Goo (2005:194) and Pantzalis and Park (2009:1610) have been blended together into the aforementioned definition for use in this study. HCE may then be considered to be a direct consequence of employee knowledge, attitude and skill.

Since the 1990's, there has been a drive to provide access to primary and secondary education for all in South Africa, as well as to ensure excellence in the quality of education (Republic of South Africa, 2010:9). Intuitive logic dictates that better education and training are requisites for enhanced employee knowledge and skills. Consequently, improving these employee characteristics is expected to result in improved HCE. In short, it may therefore be presumed that one of the outcomes expected from the government's efforts relating to education is a better quality workforce - at least a workforce better able to create value for their employers, i.e. with higher HCE. The purpose of this study is therefore to investigate whether there has been an improvement in the HCE of the employees of South African listed companies over time.

The remainder of this article is organised as follows: the next section provides the background and conceptual framework for HCE, with emphasis on the South African context; thereafter the research methodology is presented; the research results and the discussion thereof follows; and the final section provides the implications of the findings for management.

\section{Background and conceptual framework}

\section{The concept of human capital efficiency}

Human capital is one category of intellectual capital, along with structural capital and relational capital (Bontis, 1998:66; Edvinsson \& Malone, 1997:34; Stewart, 1998:75). Academic and business research on human capital usually goes hand in hand with research on intellectual capital.

Pulic (2000:706) introduced a metric for intellectual capital which was based on the efficiency with which it creates value-added. His metric, Value-Added Intellectual Coefficient (VAIC ${ }^{\mathrm{TM}}$ ), is calculated as the sum total of the value-creating efficiencies of the three components of intellectual capital. This calculation is similar to $\mathrm{P}_{2}$ on the Value-Added Scoreboard report of the United Kingdom Department for Business Innovation and Skills (BIS). $\mathrm{P}_{2}$ is a measure of the efficiency with which bought-in goods and services are transformed into value-added products and services for customers (United Kingdom, 2009:55). Pulic (2000) isolated a measure of HCE, known as value-added human capital (VAHU). VAHU referred to the value-added per unit of human capital input, and is directly calculated as value-added divided by employee expenses (Pulic, 2000:707). The use of VAHU, as a measure of HCE, is further justified by its similarity to BIS's ratio for the wealth creation efficiency of labour. 
Other measures of human capital were also considered for use in this study. Excess value of human capital (EVHC) was calculated by dividing the natural logarithm of the market value of equity per employee, by the natural logarithm of the industry median market value of equity per employee (Pantzalis \& Park, 2009:1611). It measured the market value attributable to the uniqueness of a company's employees, as compared to the average employee in the industry. Human capital training value (VT) measured a company's return on investment in training its human capital (Lajili and Zeghal, 2006:179). However, VT made no provision for the value gained from other forms of human capital accumulation and required training cost information which is not required to be disclosed in financial statements. Bontis and Fitz-enz (2002:229) constructed four human capital indicators to measure human capital effectiveness, valuation, investment and depletion. Although the attributes which these four indicators took into account were comprehensive, their measurement was very difficult to replicate because company information was required that was either confidential or not readily accessible by the public.

Viljoen (2012:101) identified a slight decline in human capital return-on-investment (HCROI) of 1.14\% from 2006 to 2010 in her research statistics, but did not attempt to identify potential causes thereof. The primary goal of her research was to develop a South African benchmark for comparing corporate human capital effectiveness - a concept which incorporates strategic management and execution. HCROI differs from VAHU through its inclusion of directors' emoluments as a strategic cost and because its returns are based on gross profit (i.e. turnover less cost of sales), while VAHU examines the value-added generated by workers.

In this study, VAHU was utilised as the HCE indicator because:

- It is easy to calculate and replicate, as it is based on financial statement data which the JSE obligates companies to make available to stakeholders three months after reporting date (JSE Limited Listing Requirements - Service Issue 13, 2010:3-7).

- The calculation is free of bias, as the annual financial statements of JSE-listed companies are required to be independently audited (JSE Limited Listing Requirements - Service Issue 13, 2010:4-4).

- It is uniform and standardised for easy comparison between companies. As the calculation of VAHU uses only universal accounting information (and not marketrelated or qualitative information) and is expressed per unit of labour cost, it is not affected by company size or location.

Firer and Stainbank (2003:32), Firer and Williams (2003:353), and Swartz, Swartz and Firer (2006:74) provided similar motivation for using $\mathrm{VAIC}^{\mathrm{TM}}$ as the measure of intellectual capital in their research.

A number of research articles were found which ranked VAHU across different industries and which investigated its impact on corporate performance. However, no studies were found locally (or internationally) which explicitly investigated the movement in HCE or VAHU, over time. Furthermore, there is a general lack of prior studies on the topic of HCE in South Africa. Local research into human capital and intellectual capital performance is still in its infancy.

\section{Development of human capital in South Africa}

Section 29 of the South African constitution enshrines the right to basic and further education for all (Republic of South Africa, 1996). Interest in the progress of HCE in South Africa was ignited by the goal of the South African government to improve access to and quality of education in the country. By 2011 , spending on education amounted to $18.2 \%$ of total government expenditure - the single largest allocation in the country's budget (Republic of South Africa, 2010:12).

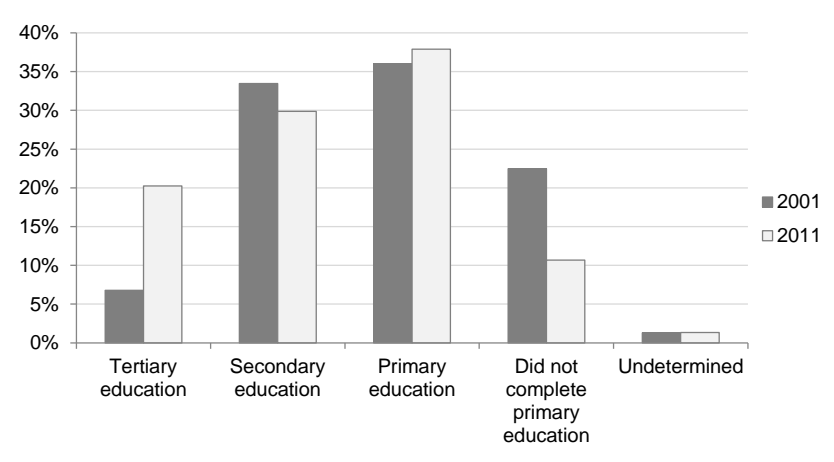

Figure 1: Labour force by level of education completed

Figure 1 depicts the proportion of South African workers who had completed primary, secondary or tertiary education by 2001 and 2011 (Statistics South Africa, 2002b; Statistics South Africa, 2012c). The number of college and university graduates in the workplace increased considerably from $6.8 \%$ to $20.2 \%$. The corresponding decrease in workers with their highest education at secondary level (from $33.5 \%$ to $29.9 \%$ ) was, therefore, expected. Similarly, the decrease in workers who did not complete primary education (from $22.5 \%$ to $10.7 \%$ ) is directly related to the increase in primary level educated workers from $36 \%$ to $37.9 \%$. These factors all point to an overall increase in the level of education reached by the South African workforce since 2001.

\section{Research methodology}

In order to investigate whether HCE has increased over time in South Africa, the following research hypothesis was formulated:

HCE in South African listed companies increased for the
financial year-ends falling in the period 31 December
2001 to 30 June 2011 .

The indicator used to measure HCE, VAHU, was extrapolated from Pulic's (2000:707) calculation of valueadded divided by payroll costs: 


$$
V A H U=\frac{\text { Earnings before interest paid, tax, salaries and wages }}{\text { Salaries and wages }}
$$

All directors' emoluments were excluded, as they are often less market-related and much higher than that of other employees.

The geometric mean of the annual rate of growth in VAHU (CAGV) over the research period was calculated per company:

$$
C A G V=\sqrt[n]{\frac{\text { End } V A H U_{1}}{\text { Start } V A H U_{1}} \times \frac{\text { End } V A H U_{2}}{\text { Start } V A H U_{2}} \times \ldots \frac{\text { End } V A H U_{n}}{\text { Start } V A H U_{n}}}-1
$$

where

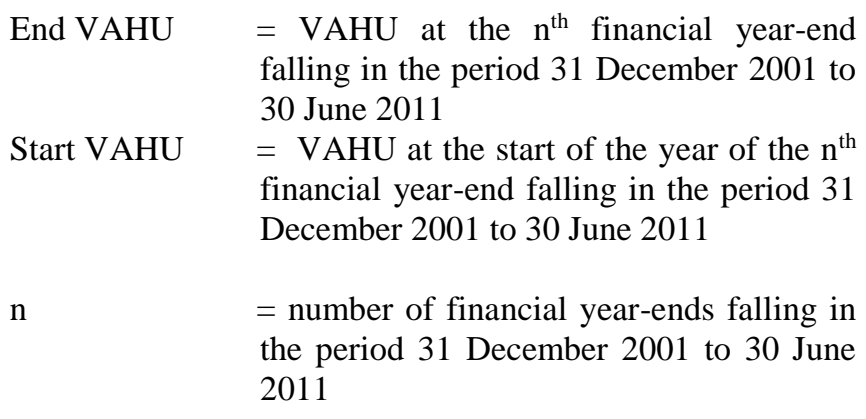

Decimal multiplier equivalents were used in the calculation of $\mathrm{CAGV}$, to avoid the problem of rooting negative growth rates.

The research hypothesis was then tested by examining the median CAGV (MGV) of all the companies listed on the JSE Main Board and ALT-X over the research period, and per industry. A Kruskal-Wallis test was then performed to confirm the statistical significance of the movement in VAHU.

The revised South African GAAP standards were harmonised with International Financial Reporting Standards in 2001 (Street, 2002:9). Based on the latest effective dates of the South African GAAP standards (SAIGR Handleiding Rekeningkunde 2000/2001, 2000), the financial statements for all financial years ending 31 December 2001 onwards were prepared after harmonisation. The research period in this study was, therefore, restricted to the financial year-ends falling in the period 31 December 2001 to 30 June 2011.

To avoid survivorship bias, the research population included all companies which were listed at any time within the research period - whether they had delisted by 30 June 2011 or were still listed. Empirical quantitative financial statement data was obtained from the McGregor Bureau of Financial Analysis database. To ensure industry categories of a reasonable size, small JSE industries containing fewer than 10 companies were grouped together with larger industries of a similar nature. The final population was comprised of 390 companies across six industries - Basic Materials (79), Consumer Goods (32), Consumer Services (56), Financials (92), Industrials (101) and Technology (30).

VAHU was found to be non-normally distributed - it displayed positive skewness of 8.6049 and strong positive kurtosis of 278.2759. The data was winsorised to address the issue of outliers - extreme values were restricted to three standard deviations from the JSE mean. The use of medians, rather than means, also minimised the effect of non-normality on the calculation of averages. However, non-normal distributions are common in financial ratios (Barnes, 1982:51; Deakin, 1976:95; So, 1987:488). They are especially common in smaller stock markets with a wide range of small-cap, mid-cap and large-cap companies, such as the JSE (Cahan, Courtenay, Gronewoller \& Upton, 2000:1296). To confirm the robustness of the VAHU analysis, a high-level supplementary test was performed using similar methodology but alternative measures of human capital performance - i.e. turnover per employee and operating profit per employee.

\section{Results}

\section{Preliminary descriptive statistics}

Higher HCE would intuitively be expected in those industries which are knowledge capital intensive (e.g. Financials, Technology and perhaps Consumer Services); and lower in Industrials, Consumer Goods and Basic Materials. The preliminary descriptive statistics in Table 1 are presented per industry and are ranked according to their median level of VAHU over the research period.

\begin{tabular}{|c|c|c|c|c|c|}
\hline & Company years & Median & Minimum & Maximum & Standard deviation \\
\hline All industries & 1765 & 1.724 & -0.325 & 4.434 & 1.190 \\
\hline Financials & 306 & 3.247 & -0.325 & 4.434 & 1.527 \\
\hline Basic Materials & 255 & 2.042 & -0.325 & 4.434 & 1.480 \\
\hline Consumer Services & 357 & 1.710 & -0.325 & 4.434 & 0.906 \\
\hline Consumer Goods & 197 & 1.695 & -0.325 & 3.187 & 0.654 \\
\hline Industrials & 492 & 1.524 & -0.325 & 4.434 & 0.833 \\
\hline
\end{tabular}

Table 1: Descriptive statistics per industry 
This VAHU ranking mostly coincides with intuitive thinking. However, HCE was found to be higher than expected in Basic Materials and lower than expected in Technology.

The unexpectedly high VAHU in Basic Materials is most likely a result of the chasm between meagre mineworker wages and the inordinate revenues earned by the mining companies. Their low wages are partly due to the perception that mineworkers are unskilled labour, and partly due to the "no-work-no-pay" principle applied during industrial action in South Africa (Republic of South Africa, 1995). By 2011, $54 \%$ of all working days lost due to industrial action in the country related to strikes in the mining sector (Republic of South Africa, 2011:17). VAHU is strong in Basic Materials because of the ability of their 'unskilled' workforce (who are untrained, unskilled and lack expertise) to generate value, despite the industry being crippled by industrial action at times.

The lower than expected VAHU observed in Technology is most likely attributable to the research-orientated nature of their operations. Much of the development of future technologies is exploratory, and ultimately may not end in a profit-generating final product. Employee costs during research and development may, therefore, be incurred without any related increases in value-added, resulting in the lower than expected level of VAHU.

\section{Movement in VAHU}

The results of the investigation into the research hypothesis (i.e. MGV and Kruskal-Wallis test) are presented in Table 2.

Table 2: Median growth in human capital efficiency from 2001 to 2011

\begin{tabular}{|c|c|}
\hline & \multirow[b]{2}{*}{2001 to 2011} \\
\hline & \\
\hline All industries & $-1.822 \%$ \\
\hline Basic Materials & $-1.523 \%$ \\
\hline Consumer Goods & $-0.354 \%$ \\
\hline Consumer Services & $0.331 \%$ \\
\hline Financials & $-5.341 \%$ \\
\hline Industrials & $-2.993 \%$ \\
\hline Technology & $-1.165 \%$ \\
\hline
\end{tabular}

\begin{tabular}{rr}
\hline $\begin{array}{c}\text { Kruskal-Wallis } \\
\text { H-statistic }\end{array}$ & $\boldsymbol{\rho}$-value \\
\hline 0.223 & 0.637 \\
0.557 & 0.455 \\
1.017 & 0.313 \\
2.275 & 0.132 \\
0.195 & 0.659 \\
3.531 & 0.060 \\
0.011 & 0.915 \\
\hline
\end{tabular}

For the financial year-ends falling in the period 31 December 2001 to 30 June 2011, the MGV for JSE-listed companies listed was negative. The results echo the findings of Viljoen (2012:101). In addition, negative MGV was found in all individual industries - with the exception of Consumer Services, which had a negligible MGV of $0.331 \%$. The Kruskal-Wallis test confirmed that the change in VAHU from 2001 to 2011 was not statistically significant in any industry, except Industrials. The decline in VAHU was statistically significant at $\mathrm{p}<0.1$ for Industrials.

Surprisingly, the industry which displayed the highest average level of VAHU (Financials) also experienced the sharpest deterioration in VAHU over time, with MGV of $-5.34 \%$. The research hypothesis was, therefore, rejected HCE has declined in almost all industries in South Africa from 2001 to 2011 , albeit not significantly.

In an ideal world, it may be expected that government spending on improving education would be coupled with a corresponding increase in HCE - particularly in developing countries. Workers of a higher quality (i.e. better educated, trained and skilled) would be entitled to higher remuneration, in exchange for generating higher value-added by delivering better products. Given the falling HCE, this scenario does not appear to be true in South Africa.

The median industry VAHU is presented diagrammatically in Figure 2, for each year from 2001 to 2011, in order to better understand the movement in HCE within each industry.

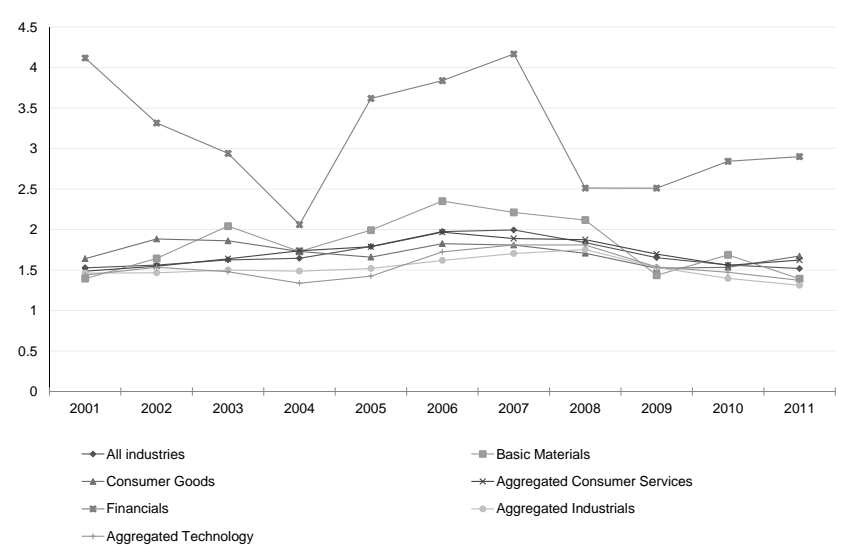

Figure 2: Movement in human capital efficiency per industry

All industries experienced a period of decline at some point between 2007 and 2009 - a recessionary effect of the global financial crisis in 2007. Financials also displayed a steep decline between 2001 and 2004, in the aftermath of the terrorist attack on the United States on 11 September 2001 (9/11). It is difficult to extract value from any company resource during times of economic instability and unpredictability, human capital included. Consequently, HCE would also be adversely affected - particularly in the industries which depend primarily on the expertise of their employees for the generation of value-added. It is not surprising that during the volatile post-2007 time period, all industries experienced some decline in VAHU - with 
knowledge-intensive Financials being the industry most sensitive to the market unpredictability.

\section{Test for robustness}

The results of the high-level supplementary test indicated a sharp increase in both turnover per employee and operating profit per employee in most industries over the research period (refer to Table 3). Although these results contradict the decline identified in VAHU, it speaks more to the need for caution in the use of 'per capita' human capital indicators than to concerns regarding the VAHU analysis.

\section{Table 3: Test for robustness}

\author{
All industries \\ Basic Materials \\ Consumer Goods \\ Consumer Services \\ Financials \\ Industrials \\ Technology
}

\begin{tabular}{cc}
\hline $\begin{array}{c}\text { Median growth in } \\
\text { real turnover } \\
\text { per employee }\end{array}$ \\
\hline & $32.481 \%$ \\
& $34.468 \%$ \\
& $28.117 \%$ \\
& $27.079 \%$ \\
& $28.285 \%$ \\
& $40.759 \%$ \\
& $29.049 \%$ \\
\hline
\end{tabular}

\begin{tabular}{cr}
\hline \multicolumn{2}{c}{$\begin{array}{c}\text { Median growth in } \\
\text { real operating profit } \\
\text { per employee }\end{array}$} \\
\hline & $20.952 \%$ \\
& $0.137 \%$ \\
& $3.693 \%$ \\
& $27.018 \%$ \\
$58.276 \%$ \\
$15.516 \%$ \\
& $54.666 \%$ \\
\hline
\end{tabular}

There is no regulation to ensure comparability between and consistency of the disclosure of numbers of employees published in company financial statements. Neither International Financial Reporting Standards nor any legislation requires mandatory disclosure of employee numbers. These numbers were further affected by the fall in permanent employment and rise in casual labour (Abbes, 2013:3) over the research period and the growing use of labour brokers to circumvent labour law (Areff, 2012). Loopholes in the legal definition of 'employee' with respect to labour brokers and temporary workers were only rectified by the Labour Relations Amendment Bill of 2012 (Republic of South Africa, 2012) - promulgated two years after the end of the research period.

The rise in real turnover per employee and operating profit per employee is therefore considered to be, in large part, the result of progressively fewer workers being disclosed as 'employees'. Fortunately, this issue does not affect the calculation of VAHU, as International Accounting Standard 19 Employee Benefits (2010:561) specifically encompasses the remuneration paid to any worker who has rendered services. The results of the test for robustness therefore indirectly lend support to the use of VAHU as a measure of human capital performance.

\section{Discussion of findings}

The negative MGV in the JSE supports Firer and Williams' (2003:357) assertion that South African companies prefer to forego further investment in the development of their human capital (and other intellectual assets), in favour of investment in technological advances in their physical assets. In addition, the growth in tangible asset spending of the companies in the research population of this study was found to exceed the growth in intangible asset spending by $33.654 \%$ over the period under review - corroborating Firer and Williams' (2003:357) finding. It may therefore be concluded that the bias between investment in physical and intellectual capital contributed to the decline in HCE.

This study, however, proposes two additional contributing factors for South Africa's falling HCE:

- The compensation paid to the South African workforce is too high in relation to the level of output delivered.

- The South African workforce is not sufficiently educated, trained and skilled.

\section{Proposition 1: Compensation is too high in relation to level of output delivered}

Although it is difficult to assess the appropriateness of worker compensation (given their level of output), it is an important consideration for the South African economy. The nominal GDP growth in South Africa of 253\% from December 2002 until December 2011 (Statistics South Africa, 2012a:12) is incommensurate with the nominal growth in annual earnings of $385 \%$ over the same period (Statistics South Africa, 2002a:10; Statistics South Africa 2012b:7). Comparable data was not available prior to 2002. The difference is alarming and it lends support to the proposition that the remuneration of South African employees became too high in relation to the level of output delivered.

The right of every employee to strike is protected by Section 23 of the South African constitution (Republic of South Africa, 1996). The impact of these strikes on a business can be far-reaching, even though striking workers receive no wages over the duration of the industrial action. The costsaving on foregone wages is outweighed by lost income and the backlog caused by delays due to striking. The true cost of downtime, i.e. the number of working days lost due to industrial action, increased from 953610 in 2001 (Republic of South Africa, 2003:12) to 2806656 in 2011 (Republic of South Africa, 2011:14). 
The 'strike' culture in South Africa, coupled with the extent of trade union involvement in the labour force, is partly responsible for the significantly higher growth in employee earnings. By 2011, 29\% of workers in the formal employment sector were members of a trade union (Statistics South Africa, 2012c:30) and $99.6 \%$ of all industrial action was sanctioned and co-ordinated by a trade union (Republic of South Africa, 2011:53). Therefore, when negotiating wage settlements (sometimes binding for many years), the collective bargaining power of trade unions was strong. Wage settlements concluded in 2011 ranged from annual increases of $6 \%$ to $14 \%$, with a median of $8 \%$ (Republic of South Africa, 2011:24). The South African inflation rate was maintained between roughly $3 \%$ and $6 \%$, by manipulating interest rates (South African Reserve Bank, 2000). It is clear that the increases in remuneration forced through industrial action exceeded inflation. This type of disparity caused cash flow pressure and contributed to the comparatively lower growth in GDP by eroding the value that might have been generated from other resources. Lower value-added, with rising wages, has negative implications for HCE. Therefore, this proposition may be accepted as a reason for the decline in VAHU.

\section{Proposition 2: Workforce is not sufficiently educated, trained and skilled}

The education statistics for the South African labour force employed as at the end of December 2001 and 2011 are presented in Figure 3 and Figure 4 (Statistics South Africa, 2002b; Statistics South Africa, 2012c).

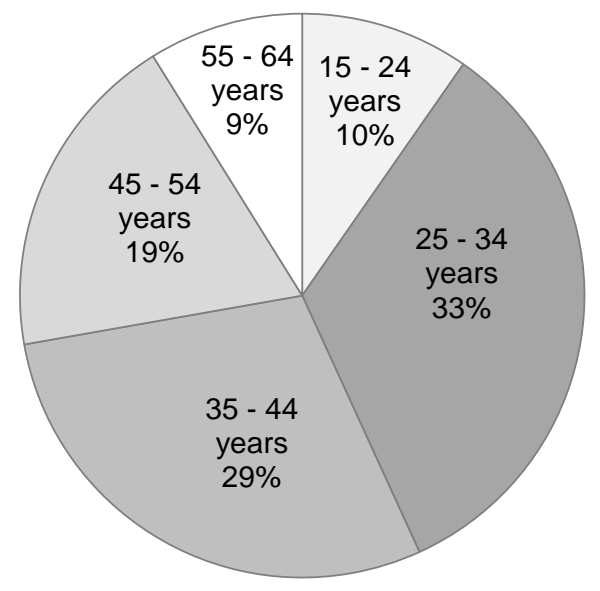

Figure 3: Labour force by age

Much negativity surrounds outcomes-based education (OBE) in South Africa. It emphasised student-centred learning, with performance measured in terms of expected proficiencies. It was initiated in Grade R to Grade 9 in 2002, then rolled out to Grades 10 to 12 in 2004 (Republic of South Africa, 2002:23 ). OBE has been the scapegoat for many of the problems experienced in the South African school system. However, given the ages of the labour force in 2011 in Figure 3, only $10 \%$ - at most - of the employees working during the research period could ever have been exposed to OBE. The majority of the workforce employed during the research period is the product of the earlier education environment which existed under Apartheid - Bantu education. The segregated and racially discriminatory curricula denied non-white students access to the same level of educational opportunities, resources and skills training offered to white students. These previously disadvantaged population groups constitute approximately $81 \%$ (in 2001) to $85 \%$ (in 2011) of the workers under review (refer to Figure 4), amplifying the negative effect of Apartheid on the education level of the labour force.

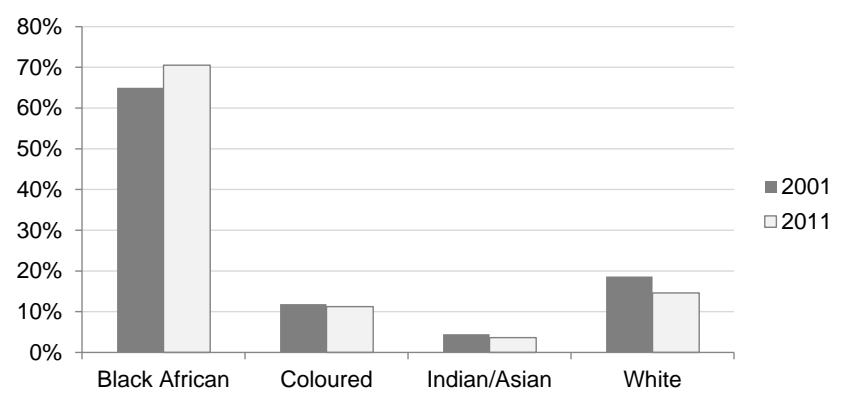

Figure 4: Labour force by population group

Southern and Eastern Africa Consortium for Monitoring Educational Quality (SACMEQ) measures the quality of education using four basic indicators - provision of basic learning materials (e.g. pencil, paper and ruler), mathematics textbooks, learner-teacher ratios and class size (SACMEQ, 2011:1). The national targets (SACMEQ, 2011:3); the results for South Africa in the SACMEQ II report of 2000 (Moloi \& Strauss, 2005) and in the SACMEQ III report of 2007 (Moloi \& Chetty, 2010), are presented in Table 4. South Africa did not participate in SACMEQ I.

Table 4: Quality of education indicators and benchmarks

$\%$ of learners with basic

learning materials

$\%$ of learners with mathematics textbooks

Learner-teacher ratios Class size

\begin{tabular}{|c|c|c|}
\hline Benchmark & 2000 & 2007 \\
\hline $100.0 \%$ & $68.0 \%$ & $82.0 \%$ \\
\hline $100.0 \%$ & $41.0 \%$ & $36.0 \%$ \\
\hline$<40$ & 37 & 37 \\
\hline$<40$ & 42 & 44 \\
\hline
\end{tabular}

It is clear that the South African education system consistently fell short of almost all targets regarding the quality of education. Most of the quality indicators worsened from 2000 to 2007. Further evidence of the deterioration of the quality of education in South Africa was provided by the World Economic Forum's annual Global Competitive Index. South Africa's ranking fell from $57^{\text {th }}$ in 2008 to $75^{\text {th }}$ in 2011 in the area of Higher Education and Training (World Economic Forum, 2008:302; World Economic Forum, 2010:302). Therefore, it appears that, although the overall level of education achieved by the South African labour force appears to have increased, the quality of education actually weakened from 2001 to 2011. The outcome of the deteriorating quality of education and the legacy effect of Bantu education is an insufficiently educated, trained and skilled workforce. Therefore, this proposition may be accepted as a reason for the decline in HCE. 
The negative implications for HCE of poor basic education in South Africa will persist for the foreseeable future, because in $2010,40.2 \%$ of learners were considered non-numerate and $27.2 \%$ were considered to be non-readers (Moloi \& Chetty, 2010:56). These learners constitute our future workforce. Many are unable to interpret meaning in a short and simple text, and are only able to perform basic calculations and simple shape recognition. It is questionable how much value-added they would be able to generate. Therefore, it appears that the country's future labour force is also at risk of lower HCE due to being insufficiently skilled.

\section{Managerial implications}

HCE in South Africa declined from 2001 to 2011. The South African tendency to develop their tangible assets instead of their intellectual capital, and the recessions experienced after 9/11 and the global financial crisis of 2007 are considered to be partly responsible. However, this study introduces two additional factors which contributed to the decline in HCE: poor basic education and excessive compensation levels imposed by the 'strike' culture in South Africa.

As a result of the deterioration in the quality of education in South Africa, most of the existing learners are competent to perform only simple calculations and are unable to read with comprehension. Unfortunately, these learners will eventually become the country's future workforce. The failure of the government's strategy for education development means that if a company wishes to improve the value-generating ability of its workforce, the company itself may be forced to shoulder the cost of further education and training to develop those requisite skills which are lacking in its employees.

By 2011, almost three million working days per annum had been lost due to constitutionally sanctioned industrial action (Republic of South Africa, 2011:14). As a result of this cost of downtime and the degree of involvement by trade unions in collective bargaining, remuneration growth substantially exceeded economic growth in the country. Therefore, the decline in HCE is partly a consequence of the erosion of value-added due to the 'strike' culture in South Africa. It is not clear which business management strategies could minimise the adverse effects of industrial action on the value-creating capability of a company's workforce. Further research is recommended to understand the relationship between industrial action (regularity, length, wage settlements, etc.) and HCE.

The product of the aforementioned factors in South Africa (poor basic education and excessive compensation due to industrial action) is a strange phenomenon - a working population that is poorly educated, with the paradox of wages that are low in relation to the cost of living, yet which are becoming too high in relation to the level of output the workers produce. The implications of this phenomenon for the value-generating ability of employees appear to differ between the various industries in South Africa. The reality for management, however, appears to be consistent: Pay your workers a fair wage, try not to buckle to trade union pressure and, if you want them to deliver better output and create value, train them to be better...yourself.

\section{References}

Abbes, M.B. 2013. Does overconfidence bias explain volatility Adcorp Holdings. 2010. Adcorp Employment Index - March 2010. [online] URL:http://www.adcorp.co.za/NEws/Documents/ Adcorp\%20Employment\%20Index_14\%20April\%202010_APPR OVED.pdf.

Areff, A. 2012. Companies use brokers to avoid labour laws, says judge, Mail \& Guardian, 1 August. [online] URL:http://mg.co.za/ article/2012-08-01-companies-use-brokers-to-avoid-labour-lawssays-judge.

Barnes, P. 1982. 'Methodological implications of non-normally distributed financial ratios', Journal for Business Finance \& Accounting, 9(1): 51-62.

Bontis, N. 1998. 'Intellectual capital: An exploratory study that develops measures and models', Management Decision, 36(2): 6376.

Bontis, N. \& Fitz-enz, J. 2002. 'Intellectual capital ROI: A causal map of human capital antecedents and consequents', Journal of Intellectual Capital, 3(3): 223-247.

Cahan, S.F., Courtenay, S.M., Gronewoller, P.L. \& Upton, D.R. 2000. 'Value relevance of mandated comprehensive income disclosure', Journal of Business Finance \& Accounting, 27(9/10): 1273-1301.

Deakin, E.B. 1976. 'Distributions of financial accounting ratios: Some empirical evidence', The Accounting Review, 51(1): 90-96.

Edvinsson, L. \& Malone, M.S. 1997. Intellectual capital: Realizing your company's true value by finding its hidden brainpower. 1st Edition. New York: Harper Business.

Firer, S. \& Stainbank, L. 2003. 'Testing the relationship between intellectual capital and a company's performance: Evidence from South Africa', Meditari Accountancy Research, 11: 25-44.

Firer, S. \& Williams, S.M. 2003. 'Intellectual capital and traditional measures of corporate performance', Journal of Intellectual Capital, 4(3): 348-360.

Garrett, M. 2013. How to make your best employees even more profitable. [online] URL:http://www.entrepreneur.com/article/ 228242.

International Accounting Standard (IAS) 19 Employee Benefits. 2010. In A Guide Through IFRS. London: IFRS Foundation.

JSE Limited Listing Requirements - Service Issue 13. 2010. [online] URL:http://www.jse.co.za/How-To-List-A-Company/MainBoard/Listing-requirements/JSE-listing-requirements.aspx.

Lajili, K. \& Zeghal, D. 2006. 'Market performance impacts of human capital disclosures', Journal of Accounting and Public Policy, 25: 171-194.

Moloi, M. Q. \& Chetty, M. 2010. The SACMEQ III Project in South Africa: A Study of the Conditions of Schooling and the Quality of Education. [online] URL:http://www.sacmeq.org/downloads/ National\%20Reports\%20SIII/S3_South_Africa_Final.pdf. 
Moloi, M., \& Strauss, J. 2005. The SACMEQ II Project in South Africa: A Study of the Conditions of Schooling and the Quality of Education. [online] URL:http://www.sacmeq.org/downloads/ sacmeqII/rsa.zip.

Pantzalis, C. \& Park, J.C. 2009. 'Equity market valuation of human capital and stock returns', Journal of Banking and Finance, 33: 1610-1623.

Pulic, A. 2000. 'VAIC ${ }^{\mathrm{TM}}$ - an accounting tool for IC management', International Journal of Technology Management, 20(5-8): 702714.

Republic of South Africa. 1995. Labour Relations Act, No. 66 of 1995. [online] URL:http://www.labour.gov.za/legislation/acts/ labour-relations/labour-relations-act.

Republic of South Africa. 1996. Constitution of the Republic of South Africa, 1996. [online] URL:http://www.info.gov.za/ documents/constitution/1996/96 cons2.htm.

Republic of South Africa. Department of Basic Education. 2010. Education for all: Country Report - South Africa. [online] URL:http://www.education.gov.za/DocumentsLibrary/Reports/tabi d/358/Default.aspx.

Republic of South Africa. Department of Education. 2002. Phasing in OBE in the FET band - Implementation strategies (2003 - 2006). [online] URL:http://www.education.gov.za/LinkClick.aspx? fileticket=1C6Z\%2fBZzl30\%3d\&tabid=452\&mid $=1038$.

Republic of South Africa. Department of Labour. 2003. Annual report on industrial action in 2003. [online] URL:http://www.labour.gov.za/documents/annual-reports/ industrial-action-annual-report/2003/industrial-action-annualreport-2003.

Republic of South Africa. Department of Labour. 2011. Annual Industrial Action Report 2011. [online] URL:http://www.labour.gov.za/documents/annual-reports/ industrial-action-annual-report/2011/industrial-action-report-2011.

Republic of South Africa. 2012. Labour Relations Amendment Bill. [online] URL:http://jutalaw.co.za/media/filestore/2012/05/b_16__2012_-_Labour_Relations_AB.pdf.

SAIGR Handleiding - Rekeningkunde 2000/2001. 2000. Kengray: The Natal Witness Printing and Publishing Company.

So, J.C. 1987. 'Some empirical evidence on the outliers and the nonnormal distribution of ratios', Journal of Business Finance \& Accounting, 14(4): 483-496.

South African Reserve Bank. 2000. Inflation targeting framework. [online] URL:http://www.resbank.co.za/MonetaryPolicy/Decision Making.

Southern and Eastern Africa Consortium for Monitoring Educational Quality (SACMEQ). 2011. Policy brief no. 2 (September 2011) - The quality of primary school inputs in South Africa. [online] URL:http://www.education. gov.za/LinkClick.aspx?fileticket=VkN1J61GKaQ\%3d\&tabid=358 $\&$ mid $=1261$.

Statistics South Africa. 2002a. Gross domestic product - Fourth quarter 2001. [online] URL:http://www.statssa.gov.za/publications/ statsdownload.asp?PPN =P0441\&SCH=863.
Statistics South Africa. 2002b. Labour Force Survey - September 2001. [online] URL:http://www.statssa.gov.za/publications/ statsdownload.asp?PPN $=\mathrm{P} 0210 \& \mathrm{SCH}=3013$.

Statistics South Africa. 2012a. Gross domestic product - Fourth quarter 2011. [online] URL:http://www.statssa.gov.za/publications/ statsdownload.asp?PPN $=\mathrm{P} 0441 \& \mathrm{SCH}=5171$.

Statistics South Africa. 2012b. Quarterly Employment Statistics December 2011. [online] URL:http://www.statssa.gov.za/ publications/statsdownload. asp? $\mathrm{PPN}=\mathrm{P} 0277 \& \mathrm{SCH}=5189$.

Statistics South Africa. 2012c. Quarterly Labour Force Survey Quarter 4 2011. [online] URL:http://www.statssa.gov.za/ publications/P0211/P02114th Quarter2011.pdf.

Stewart, T.A. 1998. Intellectual capital: The new wealth of organizations. 2nd Edition. London: Brealey.

Street, D.L. 2002. GAAP Convergence 2002 - A Survey of National Efforts to Promote and Achieve Convergence with International Financial Reporting Standards. [online] URL:http://www.iasplus.com/ resource/gaap 2002.pdf.

Swartz, G.E., Swartz, N.-P. \& Firer, S. 2006. 'An empirical examination of the value relevance of intellectual capital using the Ohlson (1995) valuation model', Meditari Accountancy Research, 14(2): $67-81$

Tseng, C. \& Goo, Y.J. 2005. 'Intellectual capital and corporate value in an emerging economy: Empirical studies of Taiwanese manufacturers', $R \& D$ Management, 35(2): 187-201.

United Kingdom. Department for Business Innovation and Skills. 2009. The 2009 Value-Added Scoreboard: The top 800 UK and 750 European companies by Value-Added - Commentary and analysis. [online] URL:http://webarchive. nationalarchives.gov.uk/ 20100908131539/http://innovation.gov.uk/value_added/downloads /2009_ValueAdded_Analysis.pdf.

Viljoen, H.H. 2012. Human Capital Return-on-Investment (HCROI) in South African Companies listed on the Johannesburg Stock Exchange (JSE). Unpublished master's thesis. Stellenbosch: Stellenbosch University.

World Economic Forum. 2008. The Global Competitiveness Report 2008-2009. [online] URL:https://members.weforum.org/pdf/ GCR08/GCR 08.pdf.

World Economic Forum. 2010. The Global Competitiveness Report 2010-2011. [online] URL:http://www3.weforum.org/docs/ WEF_GlobalCompetitivenessReport_2010-11.pdf. 